\title{
KAJIAN PENERAPAN CARA PRODUKSI YANG BAIK (CPB) DAN PENGARUH SUMBER MATA AIR TERHADAP MUTU AIR MINUM ISI ULANG (AMIU) DI KECAMATAN TEMBILAHAN HULU
}

\author{
${ }^{(1)}$ Dina Pertiwi dan ${ }^{(2)}$ Retti Ninsix, S.Tp., MP \\ (1) Alumni Teknologi Pangan Faperta UNISI \\ ${ }^{(2)}$ Dosen Teknologi Pangan Faperta UNISI
}

\begin{abstract}
Abstrak
Penelitian ini bertujuan untuk mengetahui dari mana sumber mata air yang digunakan Depot RR QUA, SPDP-99, ARAYA, Dan CACA WATER untuk diolah menjadi air minum Isi ulang, lalu apakah ada penerapan CPB pada depot air minum RR QUA, SPDP-99, ARAYA, Dan CACA WATER Dan apakah ada pencemaran bakteri Escherichia coli pada produksi air minum di sejumlah depot air minum isi ulang di Kecamatan Tembilahan Hulu.
\end{abstract}

Kata Kunci : CPB, GMP, air minum isi ulang

\section{PENDAHULUAN}

Air minum isi ulang (AMIU) merupakan salah satu alternatif bagi masyarakat dalam pemenuhan kebutuhan air minum termasuk di kecamatan Tembilahan Hulu. karna Tembilahan merupakan daerah tanah gambut dan endapan sungai rawa-rawa yang mana air tanahnya berwarna merah kecoklatan sehingga tidak bisa di konsumsi langsung. dan ini menyebabkan keberadaan depot air minum isi ulang terus meningkat sejalan dengan dinamika keperluan masyarakat terhadap air minum yang bermutu dan aman untuk di konsumsi, namun tidak semua depot air minum isi ulang terjamin keamaannya.

Untuk memeperoleh air yang aman untuk di konsumsi perlu memperhatikan cara produksi yang baik (CPB), CPB adalah suatu pedoman yang menjelaskan bagaimana memproduksi makanan atau minuman yang aman, bermutu dan layak untuk di konsumsi, CPB berisi pedomanpedoman tentang persyaratan minuman dan pengolahan umum yang harus di penuhi dalam penanganan di seluruh mata rantai pengolahan dari mulai bahan baku sampai produk akhir.

Penerapan CPB pada industry pangan memerlukan komitmen dari semua pihak baik karyawan sampai pimpinan perusahaan untuk memenuhi persyaratan yang telah di tetapkan untuk menunjang kelangsungan proses produksi.

Penerapan CPB bukan saja pada industri besar tetapi juga industri kecil seperti depot air minum RR QUA, SPDP-99, ARAYA, Dan CACA WATER yang berada di Kecamatan Tembilahan Hulu

Salah satu faktor yang penting di dalam CPB untuk Air Minum Isi ulang adalah persyaratan bahan yang digunakan dalam pengolahan seperti sumber air untuk depot isi ulang memegang peranan penting dalam menentukan kualitas air minum yang dihasilkan Depot air minum isi ulang di Kecamatan Tembilahan Hulu mengambil 
air dari beberapa sumber mata air seperti dari bukit sumber mata air seperti depot RR QUA dan ARAYA mengambil sumber air dari bukit suber mata air yang berada di Desa Sencalang Kecamatan Keritang Kabupaten Indragiri Hilir tetapi sebagian besar melakukan pengeboran kedalam tanah dengan kedalaman 140150mseperti depot air minum CACA WATER dan SPD-P99, selain itu di Kecamatan Tembilahan ini jika konsumen ingin membeli air galon isi ulang dan langsung di antar ke alamat harus menyalin air dalam galon yang di bawa petugas depot air minum ke dalam galon yang di miliki konsumen dengan menggunakan corong plastik padahal selama proses penyalinan banyak sekali bakteri patogen yang pasti akan mencemari air tersebut.

Sedangkan sebagai air minum isi ulang harus memenuhi persyaratan kualitas yang telah di tetapkan seperti tidak berasa, tidak berbau dan tidak berwarn. Namun kualitas air minum masih di ragukan karna diduga dapat terkontaminasi oleh berbagai cemaran yang dapat membahayakan kesehatan manusia jika penanganan dan pengolahannya kurang baik seperti cemaran bakteri E.coli yang merupakan indikator kualitas air minum (Tortor, 2004).

Menurut Peraturan Menteri Kesehatan No.492/MENKES/PER/IV/ 2010, persyaratan kualitas air minum untuk seluruh penyelenggara air minum wajib memenuhi persyaratan fisika, mikrobiologis, kimia dan radioaktif. Diduga sejauh ini pengusaha depot air minum isi ulang masih ada yang masih belum memenuhi kualitas air minum khususnya kualitas secara mikrobiologi.

Berdasarkan uraian di atas maka dilakukan penelitian dengan judul "Kajian penerapan cara produksi yang baik (CPB) dan Pengaruh Sumber Mata Air terhadap Mutu Air Minum Isi Ulang (AMIU) di Kecamatan Tembilahan Hulu".

\section{Tujuan Penelitian}

Penelitian ini bertujuan untuk mengetahuidari mana sumber mata air yang digunakan Depot RR QUA, SPDP99, ARAYA, Dan CACA WATER untuk diolah menjadi air minum Isi ulang, lalu apakah ada penerapan CPB pada depot air minum RR QUA, SPDP99, ARAYA, Dan CACA WATER Dan apakah ada pencemaran bakteri Escherichia coli pada produksi air minum di sejumlah depot air minum isi ulang di Kecamatan Tembilahan Hulu.

\section{Manfaat}

Adapun manfaat dari penelitian ini adalah Menambah pengetahuan mahasiwa tentang bagaimana cara produksi yang baik (CPB) dan mengetahui air isi ulang yang di cemari oleh bakteri Escherichia coli. Dan masyarakat lebih memahami tentang air minum isi ulang yang baik agar masyarakat tau dari mana sumber air yang digunakan danair minum dari depot mana yang aman serta higienis untuk di konsumsi khusunya di Kecamatan Tembilahan Hulu.

\section{METODOLOGI PENELITIAN}

\section{Bahan}

Bahan utama yang digunakan dalam penelitian ini adalah air minum isi ulang yang diperoleh dari 4 depot air minum di Kecamatan Tembilahan Hulu. Adapun bahan untuk analisa kimia adalah aquades, $\mathrm{NaOH} \quad 50$ $\%, \mathrm{H}_{2} \mathrm{SO}_{4}$ pekat, $\mathrm{H}_{3} \mathrm{BO}_{3} 2 \%, \mathrm{HCl} 0,1 \mathrm{~N}$ dan indikator metil. 
Alat

Alat yang digunakan dalam penelitian ini adalah botol sebagai wadah tempat air minum isi ulang. Sedangkan alat yang digunakan untuk analisa kimia adalah timbangan, gelas ukur, tabung reaksi, cawan petri, spoit, inkubator, autoclave, hand tally counter, oven, labu erlemeyer, gelas kimia, separatory funnel.

\section{Metode Penelitian}

Metode penelitian ini bersifat eksperimen dan diskriptif pengambilan data dan pengumpulan data dengan cara langsung pada depot air minum dan uji bakteri Escherichia coli diambil dari sampel yang diambil dari air isi ulang dari depot pengamatan langsung di lokasi.

Adapun depot air minum isi ulang yang dilakukan pengamatan adalah 4 depot air minum isi ulang yang berlokasi di Kecmatan Tembilahan Hulu.4 depot air minum isi ulang itu di harapkan dapat mewakili dari 7 depot yang terdata di data Dinas Kesehatan Kabupaten Indragiri Hilir.

\section{HASIL DAN PEMBAHASAN}

Penerapan Cara Produksi yang Baik (CPB) pada 4 Depot Air Minum Isi Ulang di Kecamatan Tembilahan Hulu

Penerapan CPB pada sebuah industri dapat di lihat dari sejauh mana aspek CPB biasa di terapkan pada industri tersebut. Aspek CPB menurut Dirjen POM (1999) terdiri dari lingkungan sarana pengolahan, bangunan dan ruangan, fasilitas sanitasi, peralatan produksi, persyaratan bahan, produk akhir, laboratorium dan pemeriksaan, kariawan, wadah dan pembungkus, keterangan produk (pelabelan), penyimpanan, pemeliharaan, dan transportasi.

Dari penelitian kajian penerapan cara produksi yang baik (CPB) dan pengaruh sumber mata air terhadap mutu air minum isi ulang di Kecamatan Tembilahan Hulu terhadap 4 depot air minum isi ulang A( RR QUA) B (SPDP99) $\mathrm{C}$ (CACA WATEER) D (ARAYA).

Kajian penerapan cara produks yang baik (CPB) dari pengisian data form $\mathrm{CPB}$ dari 4 depot air minum isi ulang, data CPB dapat dilihat pada Tabel 1.

Tabel 1. Data penerapan (CPB) dari 4 depot Air Minum Isi Ulang di Kecamatan Tembilahan Hulu

\begin{tabular}{|l|l|c|c|}
\hline No & \multicolumn{1}{|c|}{ Nama Depot } & Nilai & $\begin{array}{c}\text { Rata-Rata } \\
\text { Penerapan (CPB) }\end{array}$ \\
\hline 1 & RR QUA ( Air Dari Rengat) & 18.476 .46 & Sangat kurang \\
\hline 2 & SPD-P99 (Air Bor) & 19.775 .38 & Sangat kurang \\
\hline 3 & CACA WATER ( Air Bor) & 17.788 .46 & Sangat kurang \\
\hline 4 & ARAYA ( Air Bukit Sencalang) & 18.983 .08 & Sangat kurang \\
\hline
\end{tabular}

Dari Tabel 1 di atas dapat dilihat bahwa depot air minum SPD-P99 memiliki skor penerapan CPB paling tinggi dengan nilai 18.476.46 dan depot yang memiliki skor penerapan CPB paling rendah yaitu CACA WATER dengan nilai 17.788.46. 


$\begin{array}{lrr}\text { Beberapa } & \text { faktor } & \text { yang } \\ \text { mempengaruhi } & \text { penilaian } & \text { kategori } \\ \text { penerapan CPB yaitu seperti: } & \end{array}$

\section{Lingkungan Sarana Pengolahan}

Lingkungan sarana pengolahan terdiri dari lokasi pabrik dan sarana jalan.

a. Lokasi pabrik

Hasil perhitungan aspek lokasi pabrik pada depot A di dapat nilai aplikasi sebesar 57,14 \% yang menunjukan bahwa aspek lokasi pabrik bernilai cukup. Hal ini karna lokasie depot A. Hal ini karna lokasi pabrik terletak di daerah padat penduduk tepatnya di tepi sungai indragiri dan lokasi depot A jika hujan turun maka air hujan akan menggenangi jalan didepan lokasi depot A, selain itu saat air banjir naik maka depot A akan tergenang banjir, sehingga dapat menyebabkan terjadinya serangan hama.Hasil perhitungan aspek lokasi pabrik pada depot B di dapat nilai aplikasi sebesar $75 \%$ yang menunjukan bahwa aspek lokasi depot B bernilai cukup. karna depot B berada di lokasi padat penduduk dan terdapat genangan air sisa produksi di tambah lagi lokasi depot B pas di depan tempat penjual ikan dan sayur sehingga menyebabkan mudahnya serangan hama terhadap air hasil produksi.Hasil perhitungan aspek lokasi pabrik $\mathrm{C}$ di dapat nilai aplikasi sebesar $50 \%$ yang menunjukan bahwa aspek lokasi depot $\mathrm{C}$ bernilai cukup. Hal ini karna lokasi depot $\mathrm{C}$ berada dekat dengan tempat pembuangan sampah, di depannya banyak genangan air dan di samping tempat penampungan barang bekas selain itu berdekatan dengan pasar sehingga menyebabkan mudahnya penyerangan hama.Hasil perhitungan aspek lokasi pabrik D di dapat nilai aplikasi sebesar $72 \%$ yang menunjukan bahwa aspek lokasi depot $\mathrm{D}$ bernilai cukup. Hal ini karna lokasi depot D berada di tengan-tengah pemukiman padat penduduk dan lokasi pengolahan terdapat genangan air berupa kolam ikan lele yang mana kotorannya dapat menimbulkan serangan hamaterhadap air produksi.

Menurut Dirjen POM (1999), lingkungan di sekitar sarana pengolahan seperti lokasi pabrik, linkunganpabrik harus terawat baik, bersih bebas dari serangan hama dan tumbuhan tanaman liar.

\section{b. Sarana jalan}

Hasil aspek sarana jalan pada depot A, B, C, D di dapat nilai aplikasi sebesar $87,5 \%$ yang menunjukan bahwa aspek lokasi bernilai baik. Hal ini karna sarana jalan sudah di aspal dan seluruh depot sudah membuat saluran pembuangan air. Menurut dirjen POM (1999), sarana jalan harus di aspal dan di buat saluran pembuangan air.

\section{Bangunan dan Ruangan}

mencakup:

Bangunan dan

\section{a. Desain dan tata letak ruangan}

Hasil perhitungan aspek dan desain tata letak ruangan pada depot A di dapat nilai aplikasi sebesar $45 \%$ yang menunjukan desain tata letak ruanagn bernilai kurang. Hal ini karna tata letak tidak teratur sesuai arus proses pengolahan. Dan untuk hasil perhitungan aspek dan desain tata letak ruangan pada depot B, C, dan D di dapat nilai aplikasi sebesar $75 \%$ yang menunjukan desain tata letak ruanagn bernilai baik. Hal ini karna tata letak teratur sesuai arus proses pengolahan dimana terdapat ruangan pokok dan ruang administrasi. Menurut Dirjen POM (1999), perancangan bangunan, peralatan dan fasilitas sarana pengolahan harus dilakukan sejak awal 
agar dapat menjamin bahwa bahan pangan selama dalam proses pengolahan tidak tercemar. Bahan pencemar datang baik dari bahan bahan biologis seperti mikroba dan parasit atau bahan kimia dan kotoran lainnya. Tata letak pabrik di atur agar sesuai arus proses pengolahan agar terhindar dari kontaminasi silang.

b. Konstruksi lantai (ruang pokok)

Hasil perhitungan konstruksi lantai pada depot $\mathrm{A}$ di dapat nilai aplikasi sebesar $45 \%$ yang menunjukan konstruksi lantai bernilai kurang. Hal ini karna lantai yang terbuat dari papan dan kedap air,apabila air pasang meluap maka depot ini akan tergenang air sungai sehingga lantai menjadi berlumpur, berbau dan susah di bersihkan.Hasil perhitungan konstruksi lantai pada depot $\mathrm{B}, \mathrm{C}$ dan $\mathrm{D}$ di dapat nilai aplikasi sebesar $70 \%$ yang menunjukan konstruksi lantai bernilai cukup. Karna dari proses pengisian air kedalam galon sering kali melimpah sehingga lantai menjadi basah dan licin karna lantai terbuat dari proslen yang mudah kotor. Menurut dirjen POM (1999), kontruksi lantai harus rapat/kedap air, tahan terhadap air, garam, basah, asam dan bahan kimia lainnya, halus, tidak licin, dan mudah di bersihkan, memudahkan pengaliran air, ada lobang pembuang, penahan bau, pertemuan lantai dan dinding tidak membentuk sudut siku-siku dan tidak menyerap air.

c. Konstruksi dinding/pemisah ruangan (ruangan pokok)

Hasil perhitungan konstruksi dinding/pemisah ruangan (ruangan pokok) pada depot $\mathrm{A}$ dan $\mathrm{C}$ di dapat nilai aplikasi $25 \%$ yang menunjukan kontruksi dinding/pemisah ruangan tempat produksi dengan ruangan lainnya bernilai kurang. Karna tidak terdapat dinding pemisah anatara ruang produksi dengan ruang pelengkap.
Hasil perhitungan konstruksi dinding/pemisah ruangan (ruangan pokok) pada depot B dan D di dapat nilai aplikasi $75 \%$ yang menunjukan kontruksi dinding/pemisah ruangan tempat produksi dengan ruangan lainnya bernilai cukup. Karna terdapat dinding pemisah anatara ruang produksi dengan ruang pelengkap yang tidak membentuk sudut siku-siku dan dinding mudah di bersihkan.

Menurut Dirjen POM (1999), konstruksi dinding/pemisah ruangan (ruanagn pokok) pertemuan dinding dengan dinding dengan dinding tidak membentuk sudut siku-siku, tidak meyerap air, dan mudah dibersihkan.

\section{d. Konstruksi atap}

Hasil perhitungan konstruksi atap pada depot A,B,C dan D di dapat nilai aplikasi $100 \%$ yang menunjukan konstruksi atap bernilai baik. Hal ini karna atap tahan dan tidak bocor. Menurut Dirjen POM (1999), konstruksi atar dari bahan yang tahan lama, tahan air, tidak bocor, tidak larut air dan tidak mudah pecah.

\section{e. Konstruksi langit-langit}

Hasil perhitungan konstruksi langit-langitn pada depot $\mathrm{A}, \mathrm{B}$, dan D di dapat nilai aplikasi $95 \%$ yang menunjukan konstruksi langit-langit bernilai baik. Hal ini karna tinggi langitlangit mencapai 3 meter dan terbuat dari bahan yang baik, tidak berlobang, tidak terkelupas tidak pecah permukaan halus dan warna nya terang. Sedangkan untuk kostruksi langit langit pada depot $\mathrm{C}$ di dapat nilai aplikasi $41 \%$ yang menunjukan konstruksi langit-langit bernilai kurang. Hal ini karna langitlangit pada depot C terkelupas, berlubang, dan pecah pecah serta permukaan tidak halus dan tidak di cat. Menurut Dirjen POM (1999), konstruksi 
langit-langit tidak mudah terkelupas, tidak berlubang tidak pecah, tahan lama, mudah di bersihkan tinggi minimal 3 meter, permukaan halus, warna terang, diatas pastiuzer tidak menyerap air, dilapis cat tahan panas.

\section{f. Konstruksi pintu}

Hasil perhitungan konstruksi pintu pada depot A,B,C dan D didapat nilai aplikasi sebesar $83,3 \%$ yang menunjukan konstruksi pintu bernilai baik. Hal ini karna konstruksi pintu pada 4 depot ini terbuat dari bahan yang tahan lama, kuat dan tidak mudah pecah, serta permukaan halus warna terang dan pintu membuka keluar. Menurut dirjen POM (1999), konstruksi pintu terbuat dari bahan yang tahan lama, kuat, tidak mudah pecah, permukaan halus, warna terang, untuk toilet tidak mudah menyer air untuk ruang pengolahan pintu membuka keluar.

\section{g. Konstruksi jendela}

Hasil perhitungan konstruksi jendela pada depot A,B,C dan D di dapat nilai aplikasi $0 \%$ yang mana konstruksi jendela bernilai sangat kurang. Hal ini karna di 4 depot air minum ini tidak ada yang memiliki jendela. Menurut Dirjen Pom (1999), konstruksi jendela terbuat dari bahan tahan lama, kuat dan tidak mudah pecah, permukaan halus, warna terang, tinggi minimal 1 meter, mudah di buka/di tutup, tidak terlalu rendah, tidak terlalu banyak, tidak terlalu lebar, mudah di bersihkan, dilengkapi kasa oencegah serangga yang mudah dilepas.

\section{h. Penerangan}

Hasil perhitungan penerangan pada depot $\mathrm{A}, \mathrm{B}, \mathrm{C}$ dan $\mathrm{D}$ didapat nilai aplikasi $62,5 \%$ yang mana penerangan bernilai cukup. Hal ini karna di 4 depot ini tidak ada yang mengguanakan penutup lampu. Menurut Dirjen POM
(1999), penerangan dari lampu atau cahaya matahari harus cukup menerangi seluruh ruangan tidak remang-remang, lampu berpenutup.

\section{i. Ventilasi dan pengatur suhu}

Hasil perhitungan aspek ventilasi dan pengartur suhu pada depot A dan D di dapat nilai aplikasi $0 \%$ yang mana ventilasi dan pengatur suhu bernilai sangat kurang. Hal ini karna depot ini tidak terdapat ventilasi dan pengatur suhu, sedangkan untuk depot $\mathrm{C}$ dan $\mathrm{B}$ di dapat nilai aplikasi $50 \%$ yang mana ventilasi dan pengatur cukup. Hal ini karna ventilasi di depot ini tidak dapt mengatur suhu dengan baik, berdebu, dan tertutup oleh plang nama depot. Menurut Dirjen POM (1999), ventilasi dan pengatur suhu menjamin peredaran udara dan dapat menghilangkan gas, uap, asap, bau, debu dan panas yang dapat merugikan kesehatan, dapat mengatur suhu yang di perlukan, tidak mudah mencari produksi melalui udara yang dialirkan, lubang ventilasi harus dilengkapi dengan alat yang dapat mencegah masuknya kotoran melalui udara dan mudah dibersihkan.

\section{Fasilitas Sanitasi}

Fasilitas sanitasi terdiri dari:

a. Sarana penyediaan air.

Hasil perhitungan aspek sarana penyediaan air pada depot A, B, D didapat nilai aplikasi 83,3\% yang mana aspek sarana penyediaan air bernilai sangat baik. Hal ini karna pipa-pipa masih baru dan sangat bangus. Sedangkan untuk depot $\mathrm{C}$ didapat nilai aplikasi $50 \%$ yang mana sarana penyediaan air bersih bernilai kurang karna pipa airnya sangat kotor dan sudah dilakukan penambalan penambalan. Menurut Dirjen Pom (1999), sarana pembuangan air dan limbah saluran dan 
tempat pembuangan limbah air, tempat buangan padat dan konstruksi harus mencegah kontaminasi silang.

\section{b. Sarana pembuangan air atau limbah} Hasil perhitungan sarana pembuangan air dan limbah pada depot A,B,C dan D didapat nilai aplikasi 100\% yang mana aspek sarana pembuangan air bernilai baik. Hal ini karna limbah air pencucian galon di buang melalui saluran air. Menurut Dirjen POM (1999), sarana pembuangan air dan limbah saluran dan tempat pembuangan limbah air, tempat buangan padat dan konstruksi harus mencegah kontaminasi silang.

\section{c. Sarana toilet}

Hasil perhitungan sarana toilet untuk depot A,B,C dan D didapat nilai aplikasi sebesar 2,5\% yang mana aspek sarana toilet bernilai kurang. Hal ini karna tidak ada bak cuci tangan dan tidak ada tanda pemberitahuan bahwa setiap karyawan harus mencuci tangan setelah menggunakan toilet. Menurut Dirjen POM (1999), sarana toilet letaknya terbuka langsung dengan sarana pengolahan, dilengkapi bak cuci tangan, diberi tanda pemberitahuan bahwa setiap karyawan harus mencuci tangan setelang menggunakan toilet.

\section{Peralatan Produksi}

Hasil perhitungan peralatan produksi di depot A,B,C dan D didapat nilai aplikasi sebesar $75 \%$ yang mana aspek peralatan produksi bernilai cukup. Hal ini karna alat pengisian air jarang dibersihkan dan sikat pembersih galon pada 4 depot ini semua telah rontok dan tidak layak untuk di gunakan lagi. Menurut Dirjen POM (1999), peralatan produksi permukaan yang kontak dengan makanan halus, tidak berlobang,tidak mengelupas, tidak menyerap air, tidak berkarat, tidak mengkontaminasi (mikroorganisme, logam, minyak, pelumas, bahan bakar lainnya), mudah dibersihkan, tahan lama, tidak beracun, mudah dipindahkan wabah untuk sampah dan bahan berbahaya diberi tanda.

\section{Persyaratan Bahan}

Hasil perhitungan peralatan produksi pada depot A,B,C dan D didapat nilai aplikasi $84 \%$ yang mana aspek persyaratan bahan bernilai sangat baik karna air di dalam tangki baik dari pengeboran atau dari mata air slalu dalam keadaan tertutup dan bahan tambah sesuai izin Depkes. Menurut Dirjen POM (1999), persyaratan bahan bahan untuk produksi tidak merugilmembahayakan konsumen, bahan untuk produksi sesuai spesifikasi yang ditetapkan, bahan tambahan harus dengan izin depkes.

\section{Produk Akhir}

Hasil perhitungan produk akhir pada depot A,B,C,D didapat nilai aplikasi 50\% yang mana aspek produk akhir bernilai cukup. Hal ini karna produk akhir setelah di isi kedalam galon dan sebelum diedarkan kepasaran tidak diperiksa terlebih dahulu. Menurut Dirjen POM (1999), produk akhir harus memenuhi standar mutu yang telah ditetapkan mentri, produk akhir sebelum diedarkan harus dilakukan pemeriksaan secara organoleptik, fisika, kimia dan biologi.

\section{Laboratorium dan Pemeriksaan}

Hasil perhitungan aspek dan pemeriksaan pada depot A,B,C dan D didapat nilaiaplikasi $69,4 \%$ yang mana aspek laboratorium dan pemeriksaan didapat bernilai cukup karna tidak dilakukan pemeriksaan secara rutin terhadap produk akhir pemeriksaan dilakukan hanya 6 bulan sekali. Menurut 
Dirjen POM (1999), laboratorium dan pemeriksaan untuk setiap pemeriksaan bahan baku, bahan tambahan, bahan penolong dan produk akhir seharusnya di sediakan pedoman pemeriksaan yang menyebutkan, nama makanan, tanggal pembuatan tanggal pengambilan contoh, jumlah contoh yang diambil, kode produksi, jenis pemeriksaan yang dilakukan, kesimpulan pemeriksaan, nama pemeriksa, hal lain yang dianggap penting.

\section{Karyawan}

Aspek karyawan mencakup:

a. Kesehatan karyawan

Hasil perhitungan aspek kesehatan karyawan pada depot A,B,C dan $\mathrm{D}$ didapat nilai aplikasi sebesar $100 \%$ yang mana aspek kesehatan dan karyawan bernilai baik. Hal ini karena setiap karyawan yang sedang sakit tidak diperbolehkan bengolah atau kontak langsung dengan bahan atau produk. Menurut Dirjen POM (1999), hendaknya karyawan dalam keadaan sehat, karyawan yang sakit atau menunjukan gejala sakit tidak boleh mengolah/kontak dengan makanan.

b. Kebersihan karyawan Hasil perhitungan aspek kebersihan karyawan pada depot A,B,C dan $\mathrm{D}$ didapat nilai aplikasi $55 \%$ yang mana aspek kesehatan karyawan bernilai cukup. Hal ini karena karyawan disaat bekerja tidak menggunakan pakaian kerja, tidak menggunakan sarung tangan tidak tersedia sabun cuci tangan di toilet untuk digunakan. Menurut Dirjen POM(1999), kebersihan karyawan dapat dilihat dari selalu menjaga kesehatan badan, menggunakan pakaian kerja, dan perlengkapannya, pakaian dan perlengkapan kerja tidak boleh dibawa keluar, karyawan slalu mencuci tangan dengan sabun pada saat sesudah keluar toilet, mengolah makanan.

c. Kebiasaan karyawan

Hasil perhitungan aspek kebiasaan karyawan pada depot A,B,C dan D di dapat nilai aplikasi 100\% yang mana aspek kebiasaan karyawan bernilai baik. Menurut Dirjen POM (1999), hendaknya karyawan meninggalkan kebiasan yang dapat mencemari makanan selama bekerja.

\section{Wadah dan Pembungkus}

Hasil perhitungan aspek wadah dan pembungkus pada depot $\mathrm{A}, \mathrm{B}, \mathrm{C}$ dan $\mathrm{D}$ didapat nilai aplikasi $75 \%$ yang mana aspek wadah pembungkus bernilai cukup. Hal ini karena wadah atau galon yang di gunakan 4 depot ini banyak yang sudah bocor lalu di tambal dengan lem bakar sehingga setelah lem mengering membuat permukaan galon tidak mulus lagi sehingga dapat melukai konsumen jika mengangkat galon tersebut ke atas dispenser air. Menurut Dirjen POM (1999), wadah dan pembungkus harus memenuhi syarat dapat melindungi dan mempertahankan mutu dan isi nya terhadap pengaruh dari luar, tidak berpengaruh terhadap isi, tidak boleh merugikan dan membahayakan konsumen.

\section{Keterangan Produk (Pelabelan)}

Keterangan produk mencakup:

a. Persyaratan Label

Keterangan perhitungan aspek persyaratan label pada depot A,B,C dan D dapat di nilai aplikasi $87,5 \%$ yang mana aspek persyaratan ini bernilai cukup. hal ini karena ukuran dan kombinasi warna label berbeda dan menarik untuk di lihat.

Menurut Dirjen POM (1999), label harus dibuat memenuhi syarat menurut PP No. 69 tahun 1999 tentang 
pelabelan dan iklan pangan, dibuat dengan ukuran, kombinasi warna dan bentuk yang berbeda.

b. Idintifikasi Lot

$$
\text { Hasil perhitungan aspek }
$$

identifikasi lot pada depot A,B,C dan D didapat nilai aplikasi $100 \%$ yang mana aspek idintifikasi lot bernilai baik. Menurut Dirjen POM (1999), setiap wadah diberi tanda nama produsen dan nomor lot.

\section{Penyimpanan}

Penyimpanan mencakup:

a. Penyimpanan bahan produk

Hasil perhitungan aspek penyimpanan bahan produk pada depot A,B,C dan D didapat nilai aplikasi 85,4yang mana aspek penyimpanan bahan produk bernilai baik. Hal ini karena bahan yang tidak berbahaya dan bahan yang berbahaya disimpan dilain tempat. Menurut Dirjen POM (1999), bahan baku, bahan tambahan produk akhir disimpan terpisah didalam ruang yang bersih, bebas hama, cukup penerangan terjamin aliran udara dan suhu yang sesuai, bahan tambahan disimpan sesuai table, penyimpanan bahan mentah sebaiknya tidak langsung menyentuh lantai, dinding, jauh dari langit-langit, produk akhir juga mencantumkan nama produk, tanggal produksi, kode produksi, tanggal terimah di ruang simpan, sisa akhir, tanggal pemeriksaan, hasil pemeriksaan.

\section{b. Penyimpanan bahan berbahaya}

Hasil perhitungan aspek penyimpanan bahan berbahaya pada depot A,B,C dan D di dapat nilai aplikasi $100 \%$ yang mana aspek penyimpanan bahan berbahaya bernilai baik. Hal ini karna bahan berbahaya disimpan ditempat terpisah.Menurut Dirjen POM (1999), bahan berbahaya harus di simpan terpisah dan diawasi agar tidak mencemari bahan produksi.

c. Penyimpan wadah Hasil perhitungan aspek penyimpanan wadah pada depot A,B,C dan $\mathrm{D}$ didapat nilai aplikasi 87,5 yang mana aspek penyimpanan wadah bernilai baik. Hal ini karena wadah disimpan di tempat yang terlindungi, rapi dan di bungkus menggunakan plastic.Menurut Dirjen POM (1999), wadah di simpan rapi, wadah di simpan di tempat yang bersih dan terlindungi dari pencemaran.

d. Penyimpanan label

Hasil perhitungan aspek peyimpanan label pada depot A,B,C dan $\mathrm{D}$ didapat nilai aplikasi $100 \%$ yang mana aspek penyimpanan label bernilai baik karna label di simpan didalam laci dengan rapid an teratur. Menurut Dirjen POM (1999), label di simpan rapi dan teratur agar tidak terjadi kesalahan dalam penggunaannya.

\section{e. Penyimpanan peralatan produksi}

Hasil perhitungan aspek penyimpanan peralatan produksi pada $\operatorname{depot} \mathrm{A}, \mathrm{B}, \mathrm{C}$ dan $\mathrm{D}$ didapat nilai aplikasi $75 \%$ yang mana aspek penyimpanan peralatan produksi bernilai baik. Hal ini karna peralatan setelah di pakai di bersihkan namun tidak secara rutin.Menurut Dirjen POM (1999), peralatan yang sudah di bersihkan dan di sanitasi di simpan agar terlindung dari debu, kotoran, pencemaran lainnya.

\section{Pemeliharaan}

Hasil perhitungan aspek pemeliharaan pada depot A,B,C dan D didapat nilai aplikasi $64 \%$ yang mana aspek pemeliharaan bernilai cukup. hal ini karna tidak adanya perawatan secara teratur dan kurangnya usaha pencegahan masuknya debu dan kotoran dari luar. 
Menurut Dirjen POM (1999), bangunan dan bagian- bagiannya harus di pelihara dikarnakan tindak sanitasi secara berskala dan teratur, hingga selalu berfungsi dengan baik. Harus di lakukan pencegahan masuk nya serangga, binatang pengerat unggas dan binatang lainnya ke dalam bangunan. Menggunakan desinfektan, insektisida, rodentisida, penggunaannya harus hatihati dan di awasi agar tidak menyebabkan gangguan terhadap produk.Buangan padat harus di kumpulkan untuk dikubur, dibakar, diolah sehingga aman, buangan gas harus diatur sedemikian rupa, sehingga tidak mengganggu kesehatan. Alat dan perlengkapan yang berhubungan langsung dengan makanan, harus di bersihkan dan dikenakan tindak sanitasi secara teratur, alat perlengkapan yang tidak bersentuhan langsung dengan makanan, harus dalam keadaan bersih, alat pengangkutan dan pemindahan barang dalam bangunan unit produksi harus bersih dan mudah tidak boleh merusak barang yang di angkut atau dipindahkan, alat pengangkutan untuk mengangkut produk akhir harus bersih dapat melindungi produk sampai ketempat tujuan.

\section{Transportasi}

Transportasi mencakup:

\section{a. Persyaratan umum}

Hasil perhitungan aspek persyaratan umum pada depot A,B,C dan D didapat nilai aplikasi $100 \%$ yang mana aspek persyaratan umum bernilai baik. Hal ini karna air galon selalu dalam keadaan aman selama dalam perjalanan karena sebelum melakukan perjalanan dilakukan pemeriksaan terlebih dahulu. Menurut Dirjen POM (1999), makanan selalu dalam keadaan tertlindungi selama transportasi, jenis wadah dan alat transportasi yang digunakan tergantung dari jenis makanan dan kondisi yang dikehendaki selama transportasi.

\section{b. Persyaratan Wadah dan alat transportasi}

Hasil perhitungan aspek persyaratan wadan dan alat transportasi pada depot A,B,C dan D didapat nilai aplikasi $100 \%$ yang mana aspek persyaratan wadah dan alat transportasi bernilai baik. Hal ini karna wadah dan alat transportasi telah di bentuk sesuai keperluan bentuk kemasan air galon dan dapat di bersihkan serta dapat melindungi air dalam galon selama dalam perjalanan.Menurut Dirjen POM (1999), wadah dan alat transportasi didesain agar tidak mencemari makanan, mudah di bersihkan, memisahkan makanan dari bahan-bahan non pangan, melindungi makanan dari kontaminasi seperti kotoran.

\section{c. Pemeliharaan peralatan transportasi \\ Hasil perhitungan aspek} pemeliharaan peralatan transportasi pada depot A,B,C dan D didapat nilai aplikasi $100 \%$ yang mana aspek pemeliharaan peralatan transportasi bernilai baik. Hal ini karna wadah dan alat transportasi slalu dalam keadaan bersih dan di lakukan pemeriksaan secara rutin.Menurut Dirjen POM (1999), Wadah dan transportasi untuk makanan selalu dijaga dalam keadaan bersih, baik dan terawat, jika digunakan wadah dan alat pengangkutan jumlah nya besar di desain agar tidak tercampur antara bahan makanan dan non pangan.

\section{DAFTAR PUSTAKA}

Athena, Sukar, Hendro $M$ dan D. Anwar M. 2005. Pengaruh Pengolahan Air Depot Air Minum 
Isi Ulang dalam Menormalkan Derajat Keasaman ( $p H)$. Media Litbang Kesehatan Volume XV Nomor 2.

Buckle, K.A., R.A. Edwards. GH. Fleet dan M. Wooton. 2009. Ilmu Pangan. (diterjemahkan oleh Hari Purnomo dan Adiono, 1987). UI Press. Jakarta.

Efendy. 2003. Peranan Air Bagi Kehidupan. Gramedia. Jakarta.

Hudson, Herbert. E, Jr., 1981. Water Clarification Processes : Practical Design and Evaluation. Litton Education Publishing, Inc. United State of America

Kharismajaya, Theo,. 2013. Pengawasan Dinas Kesehatan Pemerintah Kabupaten Banyumas Terhadap Kualitas Air Minum Usaha Depot Air Minum Isi Ulang (Tinjauan Yuridis Pasal 10 Peraturan Menteri Kesehatan No. 736/MENKES/PER/VI/ 2010). Skripsi Fakultas Hukum Universitas Jenderal Soedirman.

Melliawati, Ruth. 2009. Escherichia coli dalam Kehidupan. BioTrends/ Vol.4/No.1

Peraturan Menteri Kesehatan RI. No. 492/MENKES/PER/IV/2010

Tentang Persyaratan Kualitas Air Minum.

Pradana, Yoga Ardy dan Bowo Djoko Marsono. 2013. Uji Kualitas Air Minum Isi Ulang di Kecamatan Sukodono, Sidoarjo Ditinjau dari Perilaku dan Pemeliharaan Alat. Jurnal Teknik Pomits Vol.2, No.2
Puspitasari. 2009. Verifikasi Penerapan CPB dan SSOP melalui Pengujian Produk pada Unit Pengolahan Yogurt Bandung. Institut Pertanian Bogor. Bogor.

Radji, Maksum., Anglia Puspaningrum dan Atiek Suamiati. 2010. Deteksi Cepat Bakteri Escherichia coli dalam Sampel Air dengan Metode Polymerase Reaction Menggunakan Primer 16E1 dan 16E2. Makara Sains, Vol. 14, No. 1.

Randa, Mirna Sari., 2012. Analisis Bakteri Coliform (Fekal dan Non Fekal) pada Air Sumur Kompleks Roudi Manokwari. Skripsi Program Studi Biologi Jurusan Biologi. Fakultas Matematika dan Ilmu Pengetahuan Alam Universitas Negeri Papua. Manokwari.

Sandra, Christyana dan Lilis. 2007. Hubungan Pengetahuan dan Kebiasaan Konsumen Air Minum Isi Ulang Dengan Penyakit Diare. Artikel Ilmiah Fakultas Kesehatan Masyarakat Universitas Airlangga. Surabaya.

Sawyer, Clair N., 1994. Chemistry For Environmental Engineering, Fourth Edition. McGraw-Hill, Inc. Singapore.

Widiyanti, N.L.P.M. dan N.P. Ristanti. 2004. Analisis Kualitatif Bakteri Koliform pada Depo Air Minum Isi Ulang di Kota Singaraja Bali. Jurnal Ekologi Kesehatan Vol 3 no 1. 